\title{
EFFECT OF FILLER FROM RECYCLED CONSTRUCTION WASTE ON PROPERTIES OF SELF-COMPACTING CONCRETE IN FRESH AND HARDENED STATES
}

Scientific paper / Znanstveni rad

Sandra Juradin

(Received: 2 November 2018; accepted: 10 December 2018)

University of Split, Faculty of Civil Engineering, Architecture and Geodesy, Full Professor

Corresponding author: sandra.juradin@gradst.hr

Nives Ostojić-Škomrlj

University of Split, Faculty of Civil Engineering, Architecture and Geodesy, Associate Professor

Mislav Lovrić

"JAHODA" d.o.o., mag. ing. aedif.

Nikolina Glibo

mag. ing. aedif.

\begin{abstract}
Construction waste is becoming a growing concern in the modern world. Waste recycling reduces the need for landfills and preserves natural resources. This paper investigates the possibility of using construction waste in self-compacting concrete. Fillers of various particle sizes were prepared by grinding several types of waste directly without any sorting or separation. Eighteen mixtures of concrete were prepared by varying the types and proportions of fillers and other additives, and they were tested for workability in fresh state, compressive strength, and dynamic modulus of elasticity after 7 and 28 days of hardening. Eventually, the mixtures were also tested for water absorption. Results indicated that fresh concrete samples did not meet all the requirements of selfcompacting concrete, and therefore guidelines were proposed for improving the composition of concrete.
\end{abstract}

Keywords: self-compacting concrete; filler; construction waste; workability of SCC; dynamic modulus of elasticity; strength

\section{UTJECAJ PUNILA OD RECIKLIRANOG GRAĐEVINSKOG OTPADA NA SVOJSTVA SAMOZBIJAJUĆEG BETONA U SVJEŽEM I OČVRSLOM STANJU}

Sažetak: Gomilanje građevinskog otpada postaje sve veći problem modernog svijeta. Recikliranjem građevinskog otpada smanjuje se potreba za odlagalištima i čuvaju se prirodni izvori materijala. U radu je ispitana mogućnost primjene građevinskog otpada kao punila za samozbijajuće betone. Mljevenjem otpada različitog porijekla pripremila su se punila različitih veličina čestica. Na 18 mješavina ispitana je obradivost u svježem stanju, thačna čvrstoća i dinamički modul elastičnosti na očvrslom betonu kod starosti od 7 i 28 dana, te vodoupojnost. Uzorci svježeg betona nisu zadovoljili sve uvjete za samozbijajući beton te su dane smjernice za poboljšanje sastava betona.

Ključne riječi: samozbijajući beton; punilo; građevinski otpad; obradivost SCC; dinamički modul elastičnosti; čvrstoća 
Effect of filler from recycled construction waste on properties

of self-compacting concrete in fresh and hardened states

\section{INTRODUCTION}

There are numerous reasons for recycling of construction waste, the most important ones being the preservation of non-renewable mineral resources and environment protection. Rapid urban development not only reduces the number of suitable landfills but also increases the waste from demolished buildings. Waste from new constructions, renovations, and demolitions consists of wood, concrete, glass, brick, copper wire, insulation, and other materials [1-3]. These are mostly (up to 90\%) inert and non-degradable materials for reuse or recycling. Waste containing paints, solvents, and various chemicals or that contaminated with asbestos is considered to be potentially hazardous [4].

Waste separation is a major concern in recycling, considering that minimal processing is preferred for efficient waste handling. A concrete waste can be reused directy without any additional processing for applications in hard standing, bank protection, noise barriers and embankments, and road construction [5]. In general, a material recycled from a construction waste can be used as an additive in new asphalt-concrete mixtures and various types of concrete [6].

Using recycled aggregates in a new construction is a common subject of research [7-12]. Kamal et al. [13] examined the properties of a self-compacting concrete mixture containing recycled aggregates such as crushed red bricks and ceramics instead of dolomite. Ravindrarajah [14] classified concrete waste into two categories: contaminated and free-from-contamination. Recycled aggregates need to be cleaned prior to use in new constructions, and their quality depends on the source material (waste) and method of recycling.

The amount of a powdered component required to prepare a self-compacting concrete mixture is $380-600$ $\mathrm{kg} / \mathrm{m}^{3}$, according to EFNARC $[15,16]$. Most of this component is cement, the production of which is characterized by high energy consumption and a large amount of $\mathrm{CO}_{2}$ emission [17]. Extensive research is underway to replace part of the cement with a suitable additive such as silica fume, fly ash, stone dust, metakaolin, or any recycled material. Sighn et al. [18] used brick powder, marble powder, and VMA (viscosity modifier) to improve the workability and other properties of self-compacting concrete. A team of experts from Algeria University [19] studied the impact of fine clay on the properties of self-compacting concrete. The effect of ground brick as a filler or an aggregate material on the properties of self-compacting lightweight concrete was investigated in [20]. The authors concluded that a filler with a size of less than $0.04 \mathrm{~mm}$ in combination with other additives improves the compressive strength of a concrete mixture.

This paper examines the possibility of using the fillers obtained by grinding a construction waste as an additive to a self-compacting concrete mixture.

\section{EXPERIMENTALPART}

\subsection{Materials and methods}

Table 1 shows a list of 18 mixtures of self-compacting concrete prepared using cement (CEM IIA - LL 42,5 R) of $360 \mathrm{~kg} / \mathrm{m}^{3}$ and crushed limestones with fractions of $0-4,4-8$, and $8-16 \mathrm{~mm}$. The grain-size distribution curves of the mixtures of the three fractions and the cumulative curve are shown in Figure 1. 
Effect of filler from recycled construction waste on properties of self-compacting concrete in fresh and hardened states

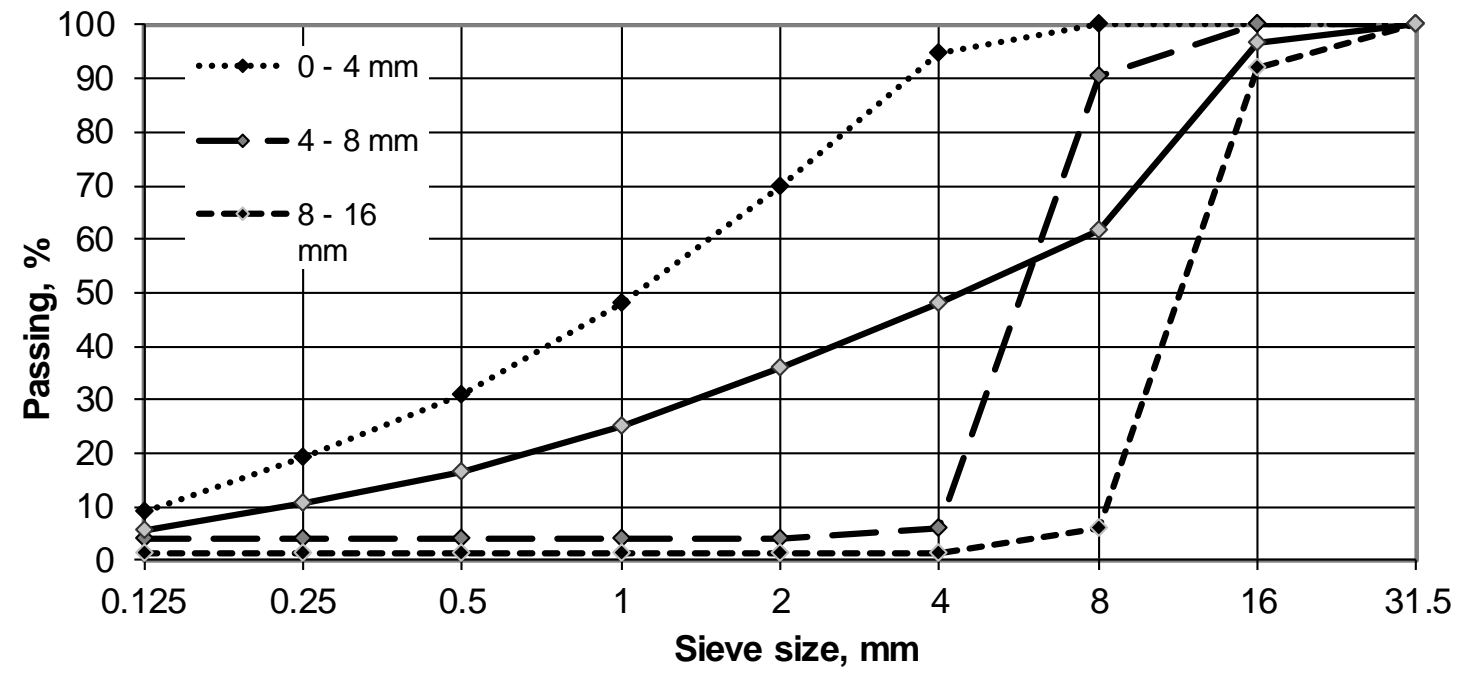

Figure 1 Grain-size distribution curves of aggregate fractions and self-compacting concrete

Two types of superplasticizer on polycarboxylate ether base of an amount of $1 \%$ of the binder by weight were added. The concrete mixtures differ from one another in respect of the additives and fillers. Three types of additives, each measuring $10 \%$ of cement by weight, were used: silica fume (SF), fly ash (FA), and metakaolin (M). Fillers commercially available in the market and/or the ones obtained by recycling were used. The commercially available fillers considered for this study were:

P1-concrete filler prepared by a cement plant by finely grinding a concrete surface using a machine, with a specific surface area of $7891 \mathrm{~cm}^{2} / \mathrm{g}$ (Blaine method), a density of $2.45 \mathrm{~g} / \mathrm{cm}^{3}$, and a percentage passing of $71 \%$ through a sieve with a mesh of $0.032 \mathrm{~mm}$.

P2-stone dust of a density of $2.7 \mathrm{~g} / \mathrm{cm}^{3}$ and a percentage passing of $86 \%$ through a sieve with a mesh of $0.032 \mathrm{~mm}$.

Fillers prepared in the laboratory were:

F1-filler obtained by grinding the rubbles of a demolished masonry structure. It consists of concrete, brick, mortar, styrofoam, glass, tiles, and other similar materials, as shown in Figure 2 (left). The unsorted waste was ground in a ball mill and then sieved through a mesh of $0.04 \mathrm{~mm}$, in accordance with the recommendations in [20]. Its density was $2.20 \mathrm{~g} / \mathrm{cm}^{3}$, and specific surface area was $10603 \mathrm{~cm}^{2} / \mathrm{g}$ (Blaine method).
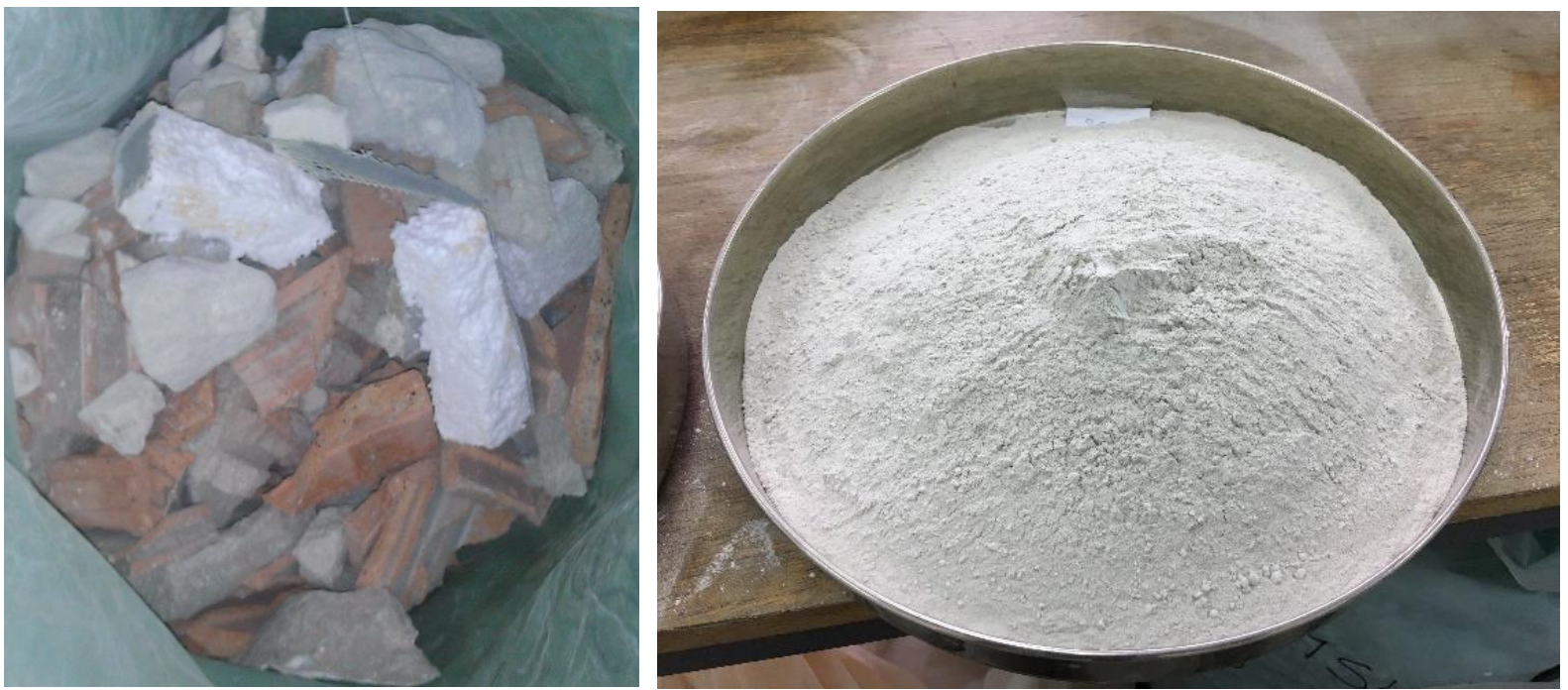

Figure 2 Material for preparation of filler F1 (left) [21] and F32 - fraction 0.063-0.125 mm (right) [22] 
Effect of filler from recycled construction waste on properties of self-compacting concrete in fresh and hardened states

F2-filler obtained by grinding concrete elements in a ball mill and sieving the powder subsequently through a sieve with a mesh of $0.04 \mathrm{~mm}$. Its density was $2.40 \mathrm{~g} / \mathrm{cm}^{3}$ and specific surface area was $9679 \mathrm{~cm}^{2} / \mathrm{g}$ (Blaine method).

F3-fillers of different fractions obtained by grinding concrete test cubes and sieving the resultant powder: F31 particles $<0.063 \mathrm{~mm}, \mathrm{~F} 32$ of $0.063-0.125 \mathrm{~mm}$ (Figure 2, right), F33 of $0.125-0.25 \mathrm{~mm}, \mathrm{~F} 34$ of $0.25-0.5 \mathrm{~mm}$, and F35 fraction comprising all particles $<0.5 \mathrm{~mm}$.

The proportion of filler for the first mixture (M1) was determined by the $\mathrm{CBI}$ method, where the minimum volume of paste was determined based on the minimum void criteria and blocking criteria [23] and the same proportion was adopted for all other mixtures. The starting water-cement ratio was 0.51 ; however, the amount of water was adjusted for the workability and visual stability of the mixture.

Table 1 Compositions and markings of mixtures

\begin{tabular}{|c|c|c|c|c|c|c|c|c|c|c|c|}
\hline \multirow{2}{*}{$\begin{array}{l}\text { Composition } \\
\text { Mixture }\end{array}$} & \multirow{2}{*}{$\begin{array}{c}\text { Cement } \\
\mathrm{kg}\end{array}$} & \multirow[b]{2}{*}{$w / c$} & \multirow[b]{2}{*}{$w / c^{* *}$} & \multicolumn{2}{|c|}{ Additive } & \multicolumn{2}{|c|}{ Filler } & \multicolumn{3}{|c|}{ Aggregate } & \multirow{2}{*}{$\begin{array}{c}\text { Admixture } \\
\mathrm{Kg}\end{array}$} \\
\hline & & & & type & $\mathrm{kg}$ & type & $\mathrm{kg}$ & $0-4 \mathrm{~mm}$ & $4-8 \mathrm{~mm}$ & 8-16 mm & \\
\hline M1 & 360 & 0.51 & 0.46 & SF & 36 & P1 & 92.88 & 810.45 & 161.57 & 649.47 & $3.96^{*}$ \\
\hline M2 & 360 & 0.51 & 0.61 & FA & 36 & P1 & 92.88 & 810.45 & 161.57 & 649.47 & 3.96 \\
\hline M3 & 360 & 0.51 & 0.59 & FA & 36 & $\begin{array}{l}P 1 \\
\text { F2 }\end{array}$ & 46.44 & 810.45 & 161.57 & 649.47 & 3.96 \\
\hline M4 & 360 & 0.51 & 0.53 & FA & 36 & $\mathrm{~F} 2$ & 92.88 & 810.45 & 161.57 & 649.47 & 3.96 \\
\hline M5 & 360 & 0.51 & 0.55 & FA & 36 & $\begin{array}{l}\text { P1 } \\
\text { E2 }\end{array}$ & $\begin{array}{l}69.66 \\
62\end{array}$ & 810.45 & 161.57 & 649.47 & 3.96 \\
\hline M6 & 360 & 0.51 & 0.58 & FA & 36 & F1 & 92.88 & 810.45 & 161.57 & 649.47 & 3.96 \\
\hline M7 & 360 & 0.51 & 0.60 & FA & 36 & $\begin{array}{l}P 1 \\
\text { F1 }\end{array}$ & $\begin{array}{l}46.44 \\
46.44\end{array}$ & 810.45 & 161.57 & 649.47 & 3.96 \\
\hline M8 & 360 & 0.51 & 0.61 & FA & 36 & $\begin{array}{l}\text { P1 } \\
\text { F1 }\end{array}$ & $\begin{array}{l}69.66 \\
23.22\end{array}$ & 810.45 & 161.57 & 649.47 & 3.96 \\
\hline M9 & 360 & 0.51 & 0.60 & SF & 36 & $\begin{array}{l}\text { P2 } \\
\text { F2 }\end{array}$ & $\begin{array}{l}69.66 \\
23.22\end{array}$ & 810.45 & 161.57 & 649.47 & 3.96 \\
\hline M10 & 360 & 0.51 & 0.55 & SF & 36 & F31 & 92.88 & 810.45 & 161.57 & 649.47 & 3.96 \\
\hline M11 & 360 & 0.51 & 0.59 & SF & 36 & F32 & 92.88 & 810.45 & 161.57 & 649.47 & 3.96 \\
\hline M12 & 360 & 0.51 & 0.58 & SF & 36 & F33 & 92.88 & 810.45 & 161.57 & 649.47 & 3.96 \\
\hline M13 & 360 & 0.51 & 0.61 & FA & 36 & F33 & 92.88 & 810.45 & 161.57 & 649.47 & 3.96 \\
\hline M14 & 360 & 0.51 & 0.59 & M & 36 & F33 & 92.88 & 810.45 & 161.57 & 649.47 & 3.96 \\
\hline M15 & 360 & 0.51 & 0.64 & SF & 36 & $\begin{array}{l}F 33 \\
F 34\end{array}$ & $\begin{array}{l}46.66 \\
46.44\end{array}$ & 810.45 & 161.57 & 649.47 & 3.96 \\
\hline M16 & 360 & 0.51 & 0.66 & SF & 36 & F35 & 92.88 & 810.45 & 161.57 & 649.47 & 3.96 \\
\hline M17 & 360 & 0.51 & 0.63 & FA & 36 & F35 & 92.88 & 810.45 & 161.57 & 649.47 & 3.96 \\
\hline M18 & 360 & 0.51 & 0.61 & M & 36 & F35 & 92.88 & 810.45 & 161.57 & 649.47 & 3.96 \\
\hline
\end{tabular}

The samples of the mixtures were tested for workability in fresh state using the methods such as the V-funnel, T500, slump-flow, J-ring, and L-box, and the sample stability was visually inspected. Subsequently, the samples were embedded in 15-cm cube-shaped molds. After $24 \mathrm{~h}$, the samples of the concrete mixtures were extracted from the molds and cured in water at $20 \pm 2{ }^{\circ} \mathrm{C}$ during the test period. After 7 and 28 days, the dynamic modulus of elasticity and compressive strength were determined using three samples from each mixture, and the remaining samples were dried at room temperature to constant weight and tested for water absorption.

\subsection{Test results of fresh concrete}

Table 2 shows the results of concrete testing in fresh state. 
Effect of filler from recycled construction waste on properties of self-compacting concrete in fresh and hardened states

Table 2 Results of fresh concrete testing

\begin{tabular}{|c|c|c|c|c|c|c|c|c|c|c|}
\hline \multirow{2}{*}{$\begin{array}{l}\text { Method } \\
\text { Mixture }\end{array}$} & \multicolumn{2}{|c|}{ V-funnel } & \multicolumn{2}{|c|}{ T500 } & \multicolumn{2}{|c|}{ Slump-flow } & \multicolumn{2}{|c|}{ J-ring } & \multicolumn{2}{|c|}{ L-box } \\
\hline & $s$ & class & $s$ & class & $m m$ & class & PJ & class & $P L$ & class \\
\hline M1 & 88.93 & & 3.17 & VS2 & 520 & - & 40 & - & 0.00 & - \\
\hline M2 & 3.19 & VF1 & 0.74 & VS1 & 485 & - & 41.25 & - & 0.46 & - \\
\hline M3 & 4.24 & VF1 & 0.91 & VS1 & 505 & - & 43.75 & - & 0.37 & - \\
\hline M4 & 5.91 & VF1 & 1.23 & VS1 & 565 & SF1 & 31.25 & - & 0.41 & - \\
\hline M5 & 3.15 & VF1 & 0.92 & VS1 & 630 & SF1 & 31.25 & - & 0.67 & - \\
\hline M6 & 3.65 & VF1 & 0.62 & VS1 & 590 & SF1 & 35 & - & 0.43 & - \\
\hline M7 & 3.45 & VF1 & 0.94 & VS1 & 607.5 & SF1 & 33.75 & - & 0.59 & - \\
\hline M8 & 6.9 & VF1 & 1.26 & VS1 & 677.5 & SF2 & 32.5 & - & 0.59 & - \\
\hline M9 & 9.26 & VF2 & 0.73 & VS1 & 640 & SF1 & 36.25 & - & 0.38 & - \\
\hline M10 & 24.31 & VF2 & 3.63 & VS2 & 465 & - & 69.5 & - & 0.08 & - \\
\hline M11 & 15.47 & VF2 & 3.28 & VS2 & 445 & - & 45 & - & 0.00 & - \\
\hline M12 & 18.19 & VF2 & 2.12 & VS2 & 525 & - & 36.25 & - & 0.06 & - \\
\hline M13 & 11.53 & VF2 & 0.69 & VS1 & 735 & SF2 & 27.5 & - & 0.71 & - \\
\hline M14 & 18.81 & VF2 & 0.66 & VS1 & 622.5 & SF1 & 36.25 & - & 0.13 & - \\
\hline M15 & 12.37 & VF2 & 0.46 & VS1 & 607.5 & SF1 & 37.5 & - & 0.44 & - \\
\hline M16 & 12.19 & VF2 & 0.46 & VS1 & 610 & SF1 & 26.25 & - & 0.35 & - \\
\hline M17 & 15.56 & VF2 & 0.88 & VS1 & 690 & SF2 & 26.25 & - & 0.73 & - \\
\hline M18 & 10.31 & VF2 & 0.41 & VS1 & 690 & SF2 & 15 & - & 0.46 & - \\
\hline
\end{tabular}

The first mixture M1 (Figure 3, right) did not satisfy the tests, and therefore another type of superplasticizer was selected. Other mixtures exhibited better leakage time; however, they could not satisfy the J-ring and L-box tests (Figure 4). The fillers obtained by grinding concrete cubes (M10-M18) increased the concrete leakage time compared to other mixtures (M2-M9). The mixtures M1-M3 and M10-M12 did not exhibit the minimum required spreading of $550 \mathrm{~mm}$ (Figure 3, left). The mixtures with fly ash, metakaolin, and F3-type filler of slightly larger particles exhibited the best workability according to the slump-flow method.

In the case of $\mathrm{M} 3$ and M10, thixotropic effect was observed when the mixing was interrupted (Figure 5).
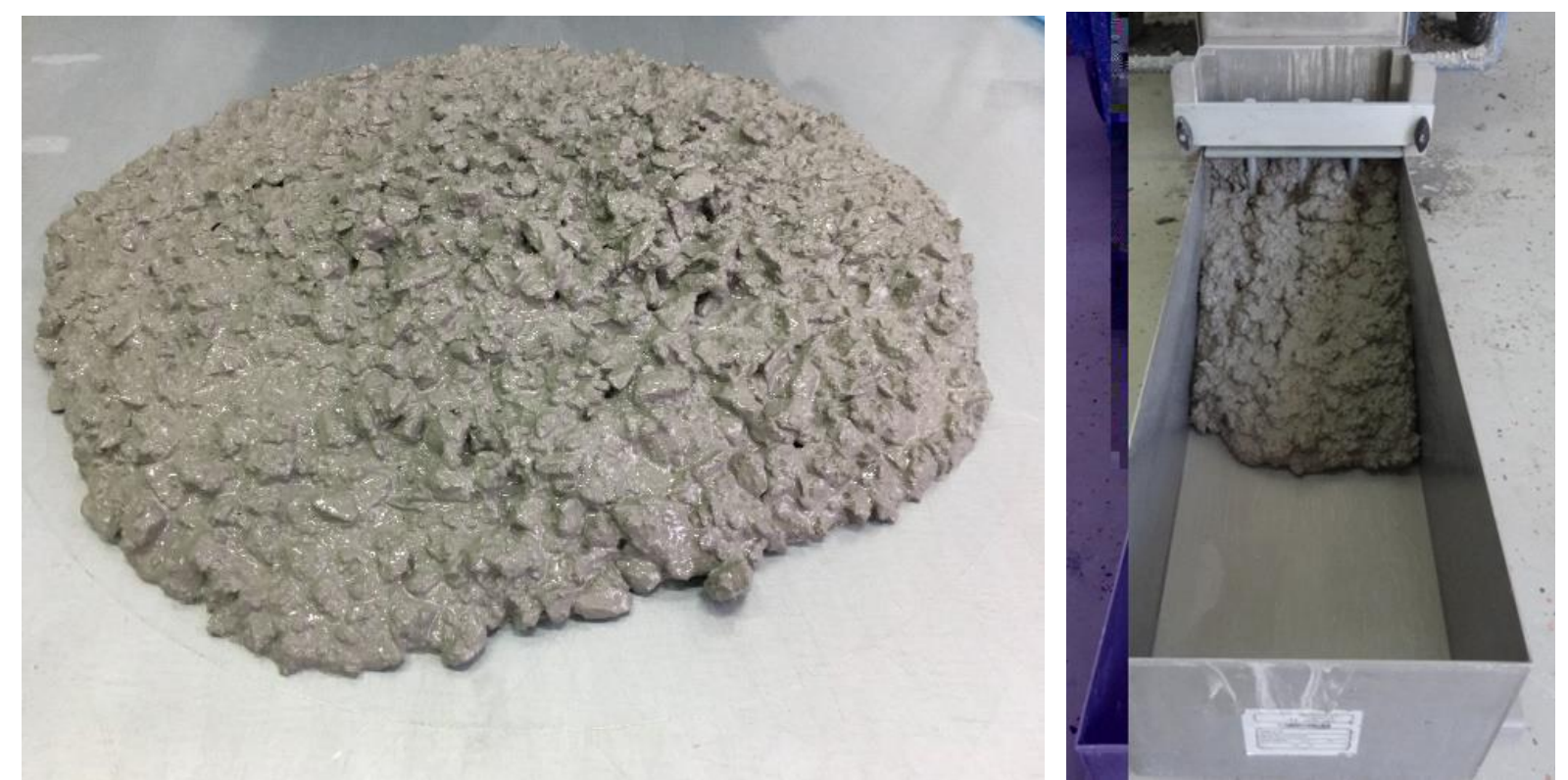

Figure 3 Mixture M10 (slump-flow) [22] and M1 (L-box) [21] 
Effect of filler from recycled construction waste on properties of self-compacting concrete in fresh and hardened states

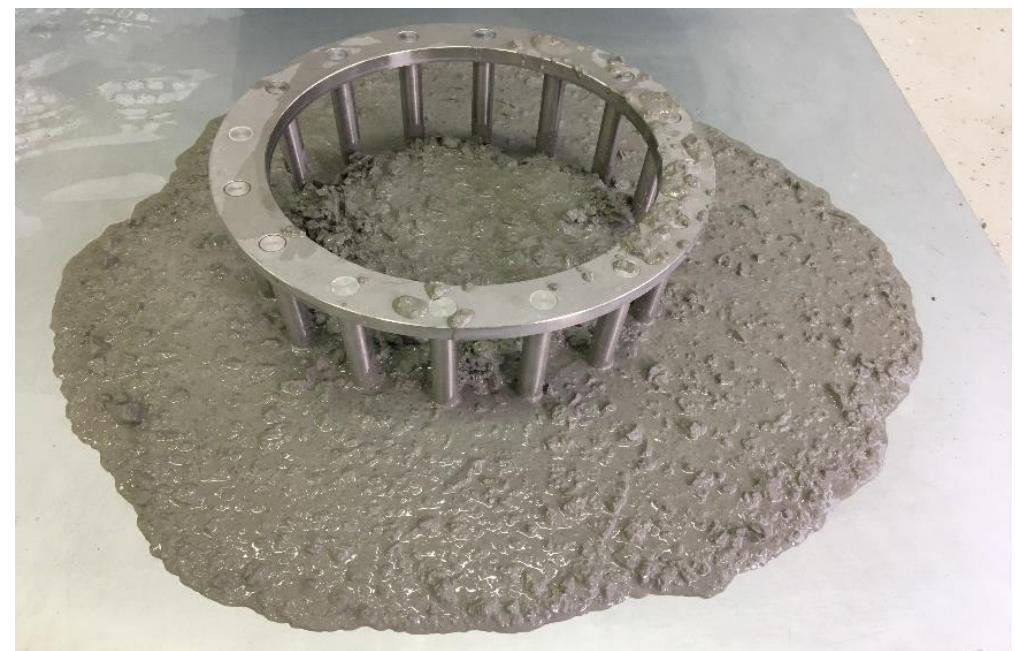

Figure 4 Testing of mixture M17 by J-ring method [22]
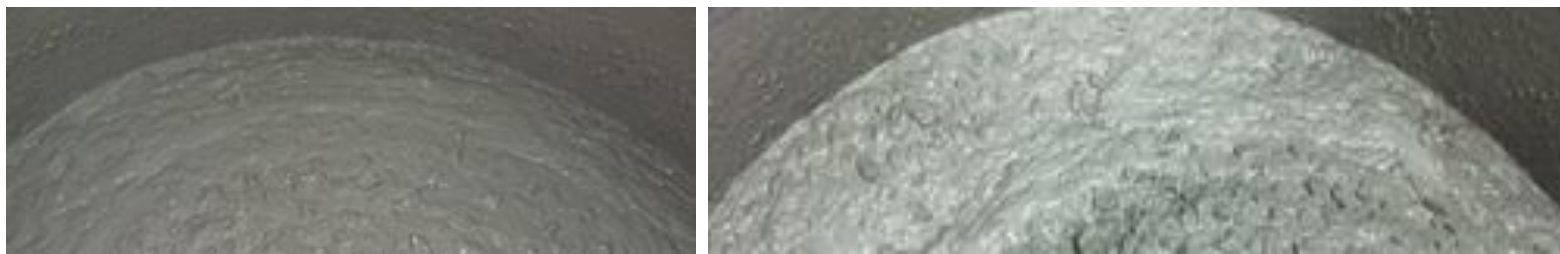

Figure 5 Mixtures M3 and M10 [21, 22]

\subsection{Test results of hardened concrete}

\subsection{Dynamic modulus of elasticity}

The samples of concrete mixtures were tested for dynamic modulus of elasticity (expressed as below) after hardening (aging) for 7 and 28 days, which are hereinafter called as 7-days and 28-days, respectively, for the sake of simplicity:

$E_{\text {din }}=\frac{v^{2} \rho(1+\mu)(1-2 \mu)}{1-\mu}$

where

$\mathrm{v}-$ mean ultrasonic wave speed $[\mathrm{m} / \mathrm{s}]$

$\rho$ - concrete density $\left[\mathrm{kg} / \mathrm{m}^{3}\right]$

$\mu-$ Poisson coefficient, $\mu=0.2$

Figure 6 shows the test results of 7-days and 28-days. In the case of 28-days, M1 exhibits the highest values, while M1-M9 exhibit higher values than M10-M18. The differences in values of 7-days and 28-days are not significant, while M10-M17 exhibit higher values for 7-days as compared to 28-days. It is possible that there was a change in the humidity of the cubes during the measurement, affecting the transit time of ultrasonic speed. 


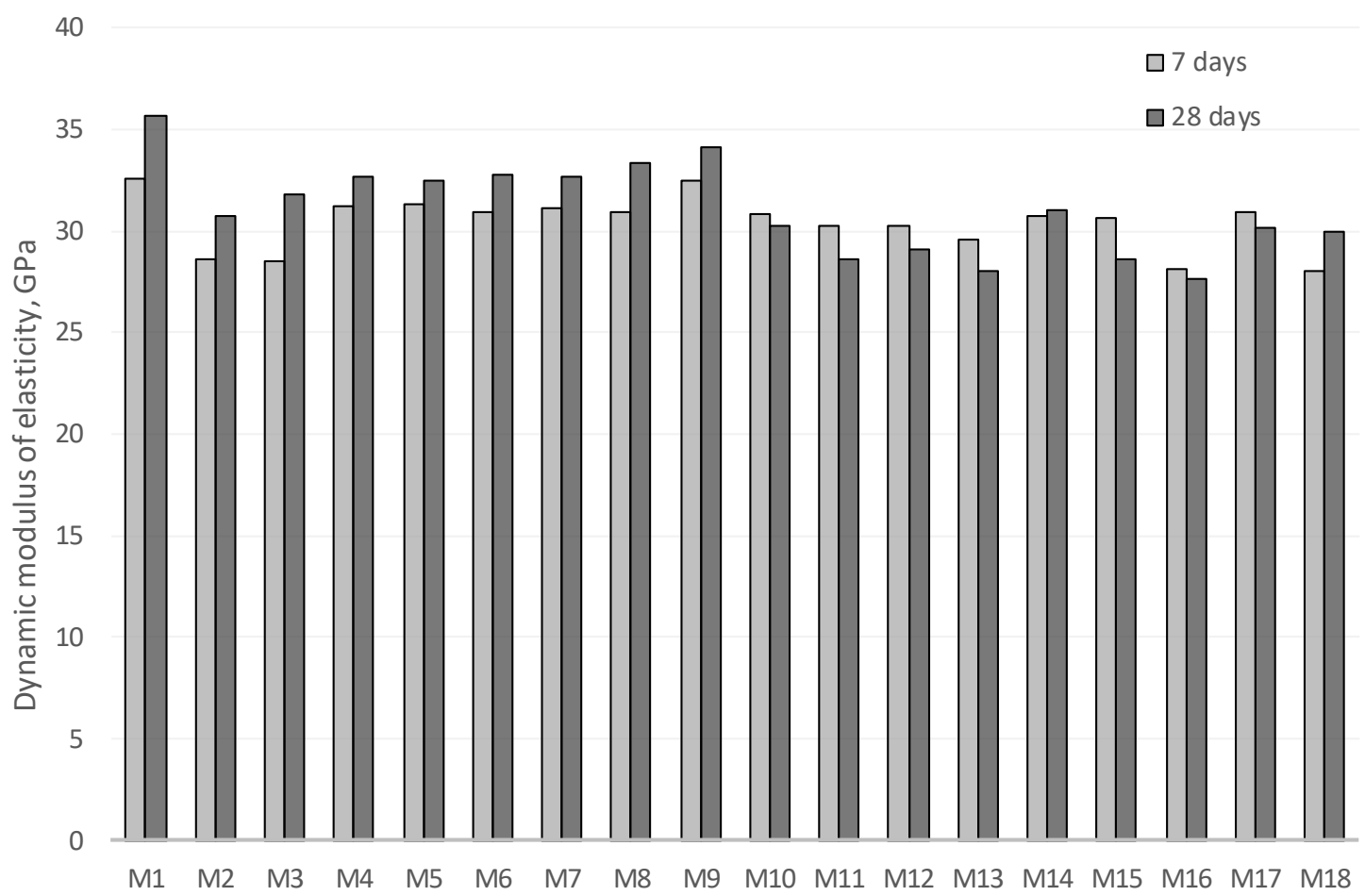

Figure 6 Dynamic modulus of elasticity after 7 and 28 days

\subsection{Compressive strength}

The results of compressive strength for 7-days and 28-days are shown in Figure 7. The values for 28-days are observed to be above $50 \mathrm{MPa}$.

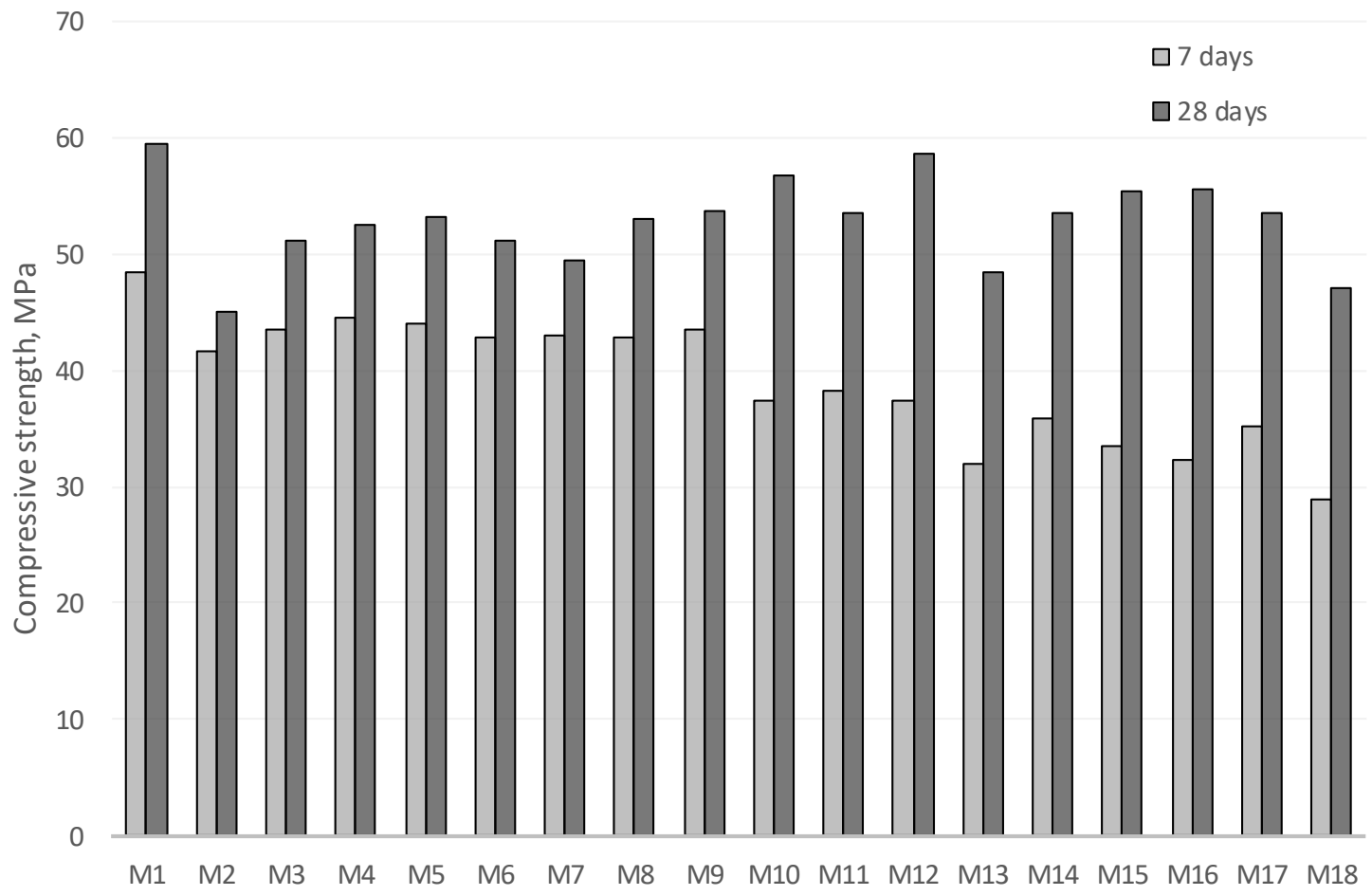

Figure 7 Compressive strength after 7 and 28 days

Juradin, S, Ostojić-Śkomrlj, N, Lovrić, M, Glibo, N 
Effect of filler from recycled construction waste on properties of self-compacting concrete in fresh and hardened states

M1 attained the best compressive strength in the case of 28-days, followed by M12, M10, M16, and M15, in decreasing order. It is observed that these are silica-fume mixtures with fillers of recycled concrete (P1 and F3). Since M1 did not meet the requirements of workability of self-compacting concrete, the strength would probably have been much better if it were prepared as a standard concrete, under the influence of vibration, as inferred from the appearance of the sample (Figure 8). Mixtures with F3-type filler exhibit higher strength increase after 7 days. This strength increase is up to $42 \%$ in relation to 28 -day strength (M16).

Mixtures with unsorted waste or filler F1 exhibit closely similar values of compressive strength. The values would probably have been higher if they were prepared with silica fume. The highest and lowest values were achieved for the mixtures with commercial filler P1, and the difference in the values was attributed to the additive (silica fume versus fly ash) and amount of water added.
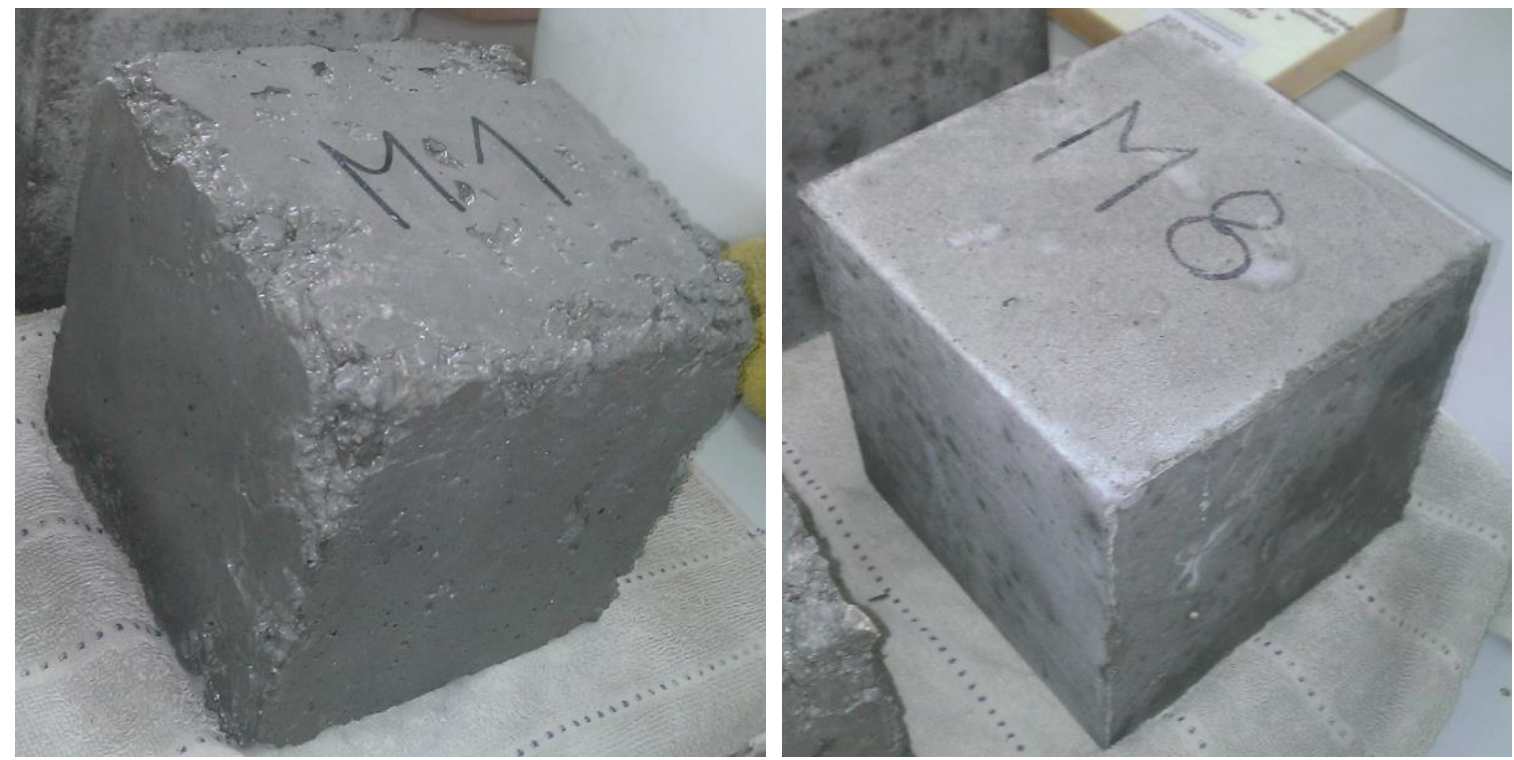

Figure 8 Samples of mixtures M1 and M8 [21]

\subsection{Absorption}

The samples dried to a constant weight at room temperature were exposed to water only on one side. The change in weight was measured after 2, 4, 8, 15, 30, 45, 60 min, and 4 and $24 \mathrm{~h}$. The change in the amount of absorbed water $(\mathrm{g})$ in relation to the initial weight of the sample is plotted with time (s) for M1-M18 in Figure 9.

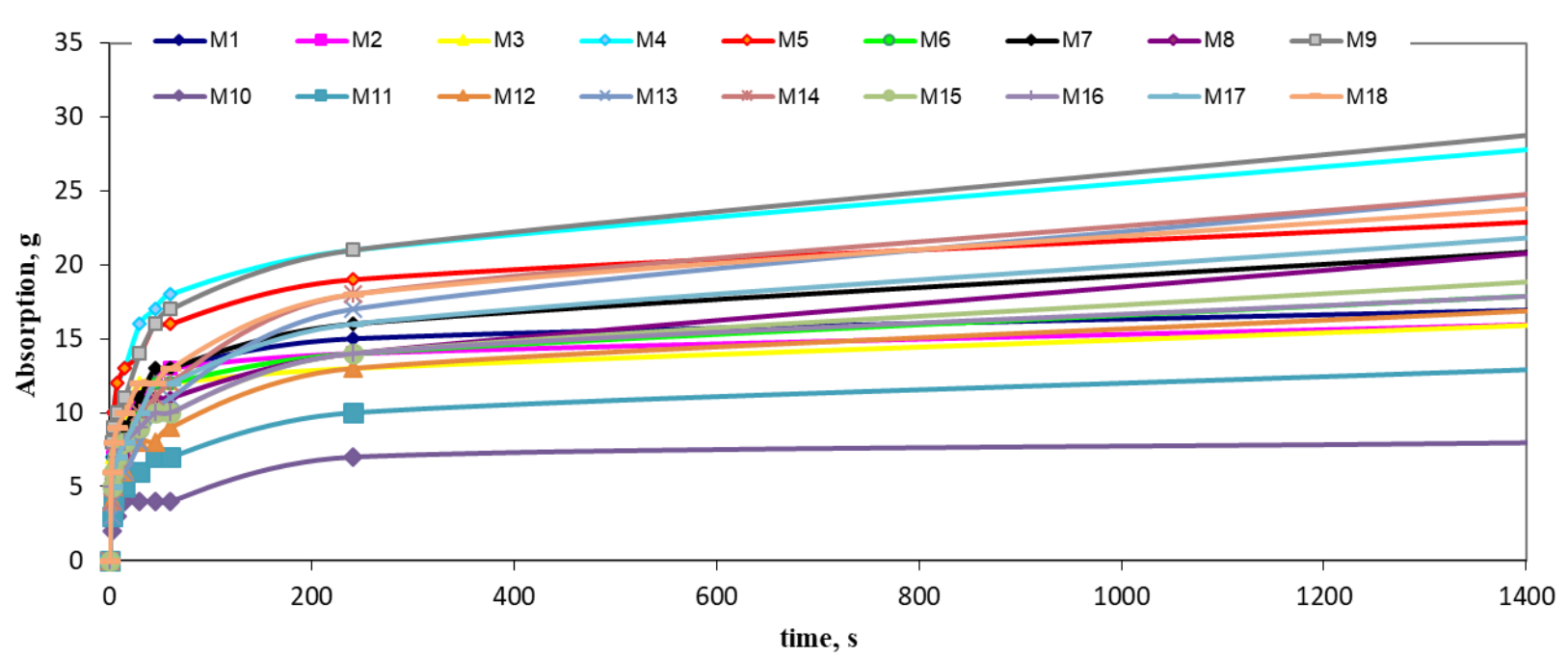

Figure 9 Absorbed water $(\mathrm{g})$ in samples M1-M18 during $24 \mathrm{~h}$ 
Effect of filler from recycled construction waste on properties

of self-compacting concrete in fresh and hardened states

The least water absorption is observed in $\mathrm{M} 10$ and $\mathrm{M} 11$, which are the mixtures with silica and filler particles (of concrete cubes) smaller than $0.063 \mathrm{~mm}$ and in the range of $0.063-0.125 \mathrm{~mm}$. The mixtures with the highest change in weight are M9, M4, and M5, prepared with F2-type filler formed by grinding concrete elements. The combination of P2-type (stone dust) and F2-type fillers in M9 exhibited the worst results, considering that the weight increased by $0.37 \%$ in relation to the inital sample weight after $24 \mathrm{~h}$. Mixtures with mixed waste exhibited intermediate values.

\section{DISCUSSION ON RESULTS}

The test results of the mixtures indicate that the fresh state of concrete, the inability to overcome the obstacles, is the major issue, while the size of spreading is a concern in a few cases. Table 3 [15] proposes the measures to improve various features of concrete. For example, it proposes to increase the water content in the concrete as a solution to reduce the viscosity.

Table 3 Possible corrective actions from identified faults [15]

\begin{tabular}{|c|c|c|c|c|}
\hline \multirow{2}{*}{$\begin{array}{c}\text { Possible improvement } \\
\text { Viscosity too high }\end{array}$} & \multicolumn{4}{|c|}{ Effect on: } \\
\hline & Filling ability & Passing ability & $\begin{array}{l}\text { Segregation } \\
\text { resistance }\end{array}$ & Strength \\
\hline increase water content & + & + & - & - \\
\hline Increase paste volume & + & + & + & + \\
\hline $\begin{array}{l}\text { increase superplasticizer } \\
\text { Yield value too high }\end{array}$ & + & + & - & + \\
\hline increase superplasticizer & + & + & - & + \\
\hline increase paste volume & + & + & + & + \\
\hline $\begin{array}{l}\text { increase mortar volume } \\
\text { Rapid loss of workability }\end{array}$ & + & + & + & + \\
\hline use different superplasticizer & $?$ & $?$ & $?$ & $?$ \\
\hline $\begin{array}{l}\text { exchange filler for cement } \\
\text { Blockage }\end{array}$ & $?$ & $?$ & $?$ & $?$ \\
\hline reduce maximum aggregate size & + & + & + & - \\
\hline increase paste volume & + & + & + & + \\
\hline increase mortar volume & + & + & + & + \\
\hline \multicolumn{5}{|c|}{$\begin{array}{l}\text { "+" indicates better results with respect to concrete properties, - indicates poorer results with respect to concrete } \\
\text { ties, and "?" means that the impact on concrete properties cannot be predicted. }\end{array}$} \\
\hline \multicolumn{5}{|c|}{$\begin{array}{l}\text { An analysis of the composition of fresh concrete according to the values recommended by EFNARC (Tab } \\
\text { dicates that the volume ratio of water to powdery component deviates from the recommended values exce } \\
11 \text { that exhibits all the parameters within the recommended values but lacks the property of self-compactin } \\
\text { rete. As the water content has already exceeded the recommended limit in a few mixtures, a measure } \\
\text { ase the water content is not applicable. Similarly, the amount of superplasticizer cannot be increased as it } \\
\text { dy at a maximum level. However, there is a possibility to add a viscosity modifier or change the type } \\
\text { rplasticizer, which is one of the recommendations as inferred from Table } 3 \text {. }\end{array}$} \\
\hline
\end{tabular}


Effect of filler from recycled construction waste on properties of self-compacting concrete in fresh and hardened states

Table 4 EFNARC parameters and actual mixture values [16]

\begin{tabular}{ccccccc}
\hline $\begin{array}{c}\text { Parameter/ } \\
\text { Typical range }\end{array}$ & $\begin{array}{c}\text { Coarse aggregate } \\
\left(\mathbf{k g} / \mathbf{m}^{3}\right)\end{array}$ & $\begin{array}{c}\text { Fine aggregate } \\
\text { weight/ } \\
\text { total aggregate }(\%)\end{array}$ & $\begin{array}{c}\text { Volume of } \\
\text { paste } \\
\left(\mathbf{L} / \mathbf{m}^{3}\right)\end{array}$ & $\begin{array}{c}\text { Mass of powdery } \\
\text { component }(\mathbf{k g})\end{array}$ & $\begin{array}{c}\text { Water } \\
(\mathbf{k g})\end{array}$ & $\begin{array}{c}\mathbf{v} / \mathbf{p} \\
\text { water/powdery } \\
\text { component (vol.) }\end{array}$ \\
\hline Mixture & $\mathbf{7 5 0 - 1 0 0 0}$ & $\mathbf{4 8 - 5 5}$ & $\mathbf{3 0 0 - 3 8 0}$ & $\mathbf{3 8 0 - 6 0 0}$ & $\mathbf{1 5 0 - 2 1 0}$ & $\mathbf{0 . 8 5 - 1 . 1 0}$ \\
M1 & 817.4 & 50 & 312 & 488.9 & 164.5 & 0.97 \\
M2 & 817.4 & 50 & 312 & 488.9 & 219 & 1.29 \\
M3 & 817.4 & 50 & 312 & 488.9 & 212 & 1.25 \\
M4 & 817.4 & 50 & 312 & 488.9 & 189 & 1.11 \\
M5 & 817.4 & 50 & 312 & 488.9 & 197 & 1.16 \\
M6 & 817.4 & 50 & 312 & 488.9 & 210 & 1.24 \\
M7 & 817.4 & 50 & 312 & 488.9 & 216 & 1.27 \\
M8 & 817.4 & 50 & 312 & 488.9 & 219 & 1.29 \\
M9 & 817.4 & 50 & 312 & 488.9 & 217 & 1.29 \\
M10 & 811.0 & 50 & 312 & 488.9 & 197.9 & 1.16 \\
M11 & 811.0 & 50 & 312 & 488.9 & 211 & 1.24 \\
M12 & 811.0 & 50 & 312 & 488.9 & 208.8 & 1.23 \\
M13 & 811.0 & 50 & 312 & 488.9 & 218.2 & 1.28 \\
M14 & 811.0 & 50 & 312 & 488.9 & 211.4 & 1.24 \\
M15 & 811.0 & 50 & 312 & 488.9 & 230.5 & 1.36 \\
M16 & 811.0 & 50 & 312 & 488.9 & 236.6 & 1.39 \\
M17 & 811.0 & 50 & 312 & 488.9 & 225.6 & 1.33 \\
M18 & 811.0 & 50 & 312 & 488.9 & 217.9 & 1.28 \\
\hline
\end{tabular}

Furthermore, Table 3 indicates that increasing the volumes of paste and mortar is a possible measure to eliminate blockage and thereby affect the workability favorably. As the volume of paste is closer to the lower recommended limit, it is possible to increase the amount of powdered component. If silica, fly ash, or metakaolin of an amount of $10 \%$ of cement by weight is added, the amount of cement could be increased by $50-100 \mathrm{~kg} \mathrm{per} \mathrm{m}^{3}$ of concrete, and the quantity of powdered component would remain within the recommended limits. Increasing the amount of cement is expected to increase the compressive strength of concrete positively.

\section{CONCLUSION}

Disposal of waste, especially construction waste, is a serious concern in the modern world. Waste recycling requires dedicated equipment, while waste separation is a time-consuming and expensive process. This paper investigates the possibility of using construction waste directly without any sorting or separation. Accordingly, in this study, the waste is ground, and the sieved powder is used to prepare concrete mixtures of various compositions that include different types of additives and fillers. The tests conducted on the concrete mixtures lead to the conclusions as follows:

- The mixtures did not qualify for the tests on blockage of self-compacting concrete; therefore, it is recommended to increase the amount of cement, add a viscosity modifier, and change the type of superplasticizer. This measure is expected to ensure better workability of concrete.

- $\quad$ Mixtures with additives such as fly ash and metakaolin and a filler of a large particle size exhibit better results in respect of slump flow.

- The best compressive strength is obtained by combining silica fume and recycled concrete.

- The finest particles of the ground concrete cubes increase the 7-day strength to a larger extent as compared to the 28-day strength. It is recommended to examine the samples after 90 days in order to explore the possibility of increasing the strength.

- Samples made of silica and filler particles of concrete cubes smaller than $0.063 \mathrm{~mm}$ and in the range of 0.063 $0.125 \mathrm{~mm}$ exhibit significantly less absorption than other samples.

- A filler obtained from mixed construction waste does not deviate from the other results.

Samples of concrete mixtures are tested in laboratories on a daily basis for compressive strength. The tested samples are disposed as construction waste. The hardened concrete mixtures prepared with silica fume and the

Juradin, S, Ostojić-Škomrlj, N, Lovrić, M, Glibo, N 
Effect of filler from recycled construction waste on properties

of self-compacting concrete in fresh and hardened states

fillers obtained by grinding concrete cubes exhibit good results. Even if the proposed changes in the composition of concrete would not improve the workability and quality of self-compacting concrete, the compressive strength achieved in this study clearly indicates that the filler can be used as an addition to ordinary concrete. It is expected that vibration will help improve the final characteristics of concrete, which can be determined by simple studies.

\section{References}

[1] Omotayo, O.O.; Akingbonmire, S.L.; Ikumapayi C.M. 2017: Sustainable application of construction and demolition waste: A review, Proceedings of the 2017 Annual Conference of the School of Engineering \& Engineering Technology (SEET), The Federal SEET'17 University of Technology, Akure, Nigeria, 11-13 July, 2017, $\mathrm{pp}$.

$596-611$, https://www.researchgate.net/publication/318601743_SUSTAINABLE_APPLICATION_OF_CONSTRUCTIO N_AND_DEMOLITION_WASTE_A_REVIEW, Accessed 12 November 2018.

[2] Zahedian, T.; Montaser Kouhsari, R. 2008: Investigate approaches materials in construction waste management, First National Conference on Engineering and Construction Management, Tehran.

[3] Abkenari, M.; Rezaei, A.; Pournayeb, N. 2015: Recycling Construction Waste Materials to Reduce the Environmental Pollutants, WASET International Journal of Civil and Environmental Engineering, 9 (8), pp. 1138-1142, https://waset.org/publications/10006145/recycling-construction-waste-materials-to-reduce-theenvironmental-pollutants, Accessed 17 November 2018.

[4] Husain, A.; Assas, M.M. 2013: Utilization of demolished concrete waste for new construction, WASET, international Journal of Civil and Environmental Engineering, 7 (1), pp. 37-42. https://waset.org/publications/8588/utlization-of-demolished-concrete-waste-for-new-construction Accessed 17 November 2018.

[5] Hendriks, Ch. F.; Janssen G.M.T. 2001: Application of construction and demolition waste, HERON, 46 (2), pp. $\quad 95-108 . \quad \quad$ htps://repository.tudelft. nl/islandora/object/uuid:87f7f6c5-9817-47dc-b0cf8bc68f4716b7?collection=research Accessed 15 November 2018.

[6] Banjad Pečur, I.; Štirmer, N. 2012: Primjena recikliranog bagregata u betonu-iskustva u Hrvatskoj, IRMA Inštitut za raziskavo materialov in aplikacije, 2012. pp. 51-62. (in Croatian), https://bib.irb.hr/datoteka/581302.Kolokvij_o_betonu_Banjad_Peur_tirmer_2012.docx, Accessed 14 October 2018.

[7] Rahal, K. 2007: Mechanical properties of concrete with recycled coarse aggregate, Building and Environment, 42 (1), pp. 407-415. https://doi.org/10.1016/j.buildenv.2005.07.033

[8] Debieb, F.; Courard, L.; Kenai, S.; Degeimbre, R. 2010: Mechanical and durability properties of concrete using contaminated recycled aggregates, Cement and Concrete Composites, 32 (6), pp. 421-426. https://doi.org/10.1016/i.cemconcomp.2010.03.004

[9] Fonseca, N.; de Brito, J.; Evangelista, L. 2011: The influence of curing conditions on the mechanical performance of concrete made with recycled concrete waste, Cement and Concrete Composites, 33 (6), pp. 637-643. https://doi. org/10.1016/j.cemconcomp.2011.04.002

[10] Bairagi, N.K.; Vidyadhara, H.S.; Ravande, K. 1990: Mix design procedure for recycled aggregate concrete, Construction and Building Materials, 4 (4), pp.188-193. https://doi.org/10.1016/0950-0618(90)90039-4

[11] Bairagi, N.K.; Ravande, K.; Pareek, V.K. 1993: Behaviour of concrete with different proportions of natural and recycled aggregates, Resources, Conservation and Recycling, 9 (1-2), pp. 109-126. https://doi.org/10.1016/0921-3449(93)90036-F

[12] Kesegić, I.; Bjegović, D.; Netinger, I. 2009: Upotreba reciklirane opeke kao agregata za beton, Građevinar 61 (1), pp. 15-22. (in Croatian), http://www.casopis-gradjevinar.hr/arhiva/article/154 Accessed 10 November 2017.

[13] Kamal, M.M.; Safan, M.A.; Etman, Z.A.; Eldaboly, E.A. 2013: Evaluating the Prolonged Properties of Fresh Self-Compacting Concrete Incorporating Recycled Aggregates, International Journal of Current Engineering and Technology, 3 (2), pp. 436-446. http://inpressco.com/wp-content/uploads/2013/05/Paper39436-4461.pdf Accessed 10 November 2018.

[14] Sri Ravindrarajah, R. 1987: Utilization of waste concrete for new construction, Conservation \& Recycling, 10 (2-3), pp. 69-74. htps://doi.org/10.1016/0361-3658(87)90127-5 
Effect of filler from recycled construction waste on properties

of self-compacting concrete in fresh and hardened states

[15] EFNARC, 2002: Specification and Guidelines for Self-Compacting Concrete, Association House, Farnham, www.efnarc.org Accessed 3 November 2018.

[16] BIBM, CEMBUREAU, ERMCO, EFCA, EFNARC, 2005: The European Guidelines for Self-Compacting Concrete, Specification, Production and Use.

[17] Moriconi, G. 2010: Sustainability-driven innovation in the society of the future, Second International Conference on Sustainable construction materials and technologies. Ancona, Milwaukee

[18] Ranjodh S.; Rohin K.; Gurniwaz S., 2013: Study of Self Compacting Concrete Using Brick Dust and Marble Powder, International Journal of Engineering Research and Applications (IJERA) 3 (3), pp. 1283-1286. http://www.ijera.com/papers/Vol3_issue3/HI3312831286.pdf Accessed 3 November 2018.

[19] Abib, Z.E; Gaher-Abib, H.; Kharchi, F. 2013: Effect of Clay Fines on the Behavior of Self-Compacting Concrete, Engineering, 5, pp. 213-218. https://ile.scirp.org/pdf/ENG_2013021809045792.pdf Accessed 3 November 2018.

[20] Juradin, S.; Grbeša, K. 2015: Influence of Ground Clay Brick on the Properties of Fresh and Hardened Self Compacting Lightweight Concrete (SCLC), Advanced Materials Research, 1106, pp. 57-60. https://doi.org/10.4028/www.scientific. net/AMR.1106.57

[21] Lovrić, M. 2016: Utjecaj punila od betonskog otpada na svojstva samozbijajućeg betona, Final Thesis, University of Split, Faculty of Civil Engineering, Architecture and Geodesy. (in Croatian)

[22] Glibo, N. 2017: Samozbijajući beton s dodatkom punila od mljevenih ispitnih betonskih kocaka, Final Thesis, University of Split, Faculty of Civil Engineering, Architecture and Geodesy. (in Croatian)

[23] Billberg, P. 2002: CBI Mix Design Model for Self-Compacting concrete, Ph.D. course - Rheology of Cementitious Materials - Self-Compacting Concrete, DTU - Technical University of Denmark, Lingby

Please cite this article as:

Juradin, S.; Ostojić-Škomrlj, N.; Lovrić, M.; Glibo, N.: Application of different seismic analyses to RC structures, Electronic Journal of the Faculty of Civil Engineering Osijek-e-GFOS, 2018, 17, pp. 52-63, https://doi.org/10.13167/2018.17.6 